\title{
Soil Carbon and Nitrogen Stock as Affected by Agricultural Wastes in a Typic Haplusult of Owerri, Southeastern Nigeria
}

\author{
Stanley Uchenna Onwudike*, Bethel Ugochukwu Uzoho, Bernadine Ngozi Ndukwu, Innocent \\ Uzoma Opara, Ojinere Clitton Anyamele
}

Department of Soil Science and Technology, Federal University of Technology Owerri, Imo State Nigeria

\section{A R T I C L E I N F O}

\section{Article history:}

Received 02 March 2016

Accepted 06 June 2016

Available online, ISSN: 2148-127X

\section{Keywords:}

Carbon stock

Nitrogen stock

Sequestration

Agro-wastes

Typic haplusult

\section{A B S T R A C T}

We evaluated the effect of saw dust ash (SDA) and poultry droppings (PD) on soil physico-chemical properties, soil carbon and nitrogen stock and their effects on the growth and yield of okra (Abelmoshus esculentus) on a typic haplusult in Owerri, Imo State Southeastern Nigeria. The experiment was a factorial experiment consisted of saw dust ash applied at the rates of 0,5 and $10 \mathrm{t} / \mathrm{ha}$ and poultry droppings applied at the rates of 0,5 and $10 \mathrm{t} / \mathrm{ha}$. The treatments were laid out in a randomized complete block design and replicated four times. Results showed that plots amended with $10 \mathrm{t} / \mathrm{ha} \mathrm{PD}+10 \mathrm{t} / \mathrm{ha}$ SDA significantly reduced soil bulk density from $1.37-1.07 \mathrm{~g} / \mathrm{cm}^{3}$, increased soil total porosity from $48.4-59.7 \%$ and the percentage of soil weight that is water (soil gravimetric moisture content) was increased by $68.4 \%$. There were significant improvements on soil chemical properties with plots amended with $10 \mathrm{t} / \mathrm{ha} \mathrm{PD}+10 \mathrm{t} / \mathrm{ha}$ SDA recording the highest values on soil organic carbon, soil total nitrogen and exchangeable bases. Plots amended with 10 t/ha PD +10 t/ha SDA significantly increased soil carbon stock by $24 \%$ and soil nitrogen stock by $49.5 \%$ more than other treatments. There was significant increase in the growth of okra when compared to the un-amended soil with application of $10 \mathrm{t} / \mathrm{ha} \mathrm{PD}+10 \mathrm{t} / \mathrm{ha}$ SDA increasing the fresh okra pod yield by $78.5 \%$. Significant positive correlation existed between SCS and organic carbon $(\mathrm{r}=0.6128)$, exchangeable $\mathrm{Mg}(\mathrm{r}=0.5035)$, total nitrogen $(\mathrm{r}=0.6167)$ and soil $\mathrm{pH}$ $(\mathrm{r}=0.5221)$. SNS correlated positively with organic carbon $(\mathrm{r}=0.5834)$, total nitrogen $(\mathrm{r}=0.6101)$ and soil $\mathrm{pH}(\mathrm{r}=5150)$. Therefore applications of these agro-wastes are effective in improving soil properties, increasing soil carbon and nitrogen stock. From the results of the work, application of $10 \mathrm{t} / \mathrm{ha} \mathrm{PD}+10 \mathrm{t} / \mathrm{ha} \mathrm{SDA}$ which was the treatment combination that improved soil properties and growth performances of okra than other treatments studied is hereby recommended for soil carbon and nitrogen stock improvement and okra production in the region.
${ }^{*}$ Corresponding Author:

E-mail: onwudikestanley@yahoo.com through agriculture, large quantities of agro-wastes such as poultry droppings, saw dust and pig dung are generated in both rural and urban cities. These wastes are found in large quantities, deposited either on or along the road sides, unapproved areas, open dump sites in the markets or in water ways (Tariq et al., 2013) and management of these wastes has been an environmental challenge (Nwachukwu, 2008) as their improper utilization has resulted to environmental pollution and contamination of the atmosphere as well as contamination of underground and surface water bodies (Kalu, et al., 2009).

Before now, the use of inorganic fertilizers in crop production has been a panacea for nutrient losses with little knowledge on its negative effect on soil condition such as acidification, nutrient imbalance and trace element deficiencies (Ajaz et al., 2013). Asadu and Nweke (1999) have reported that in Sub -Saharan Africa, soils where inorganic fertilizer are applied for arable crop production have lower nutrient elements when compared 
to soils where organic fertilizers were used. Therefore, an agricultural practice that is based solely on intensive use of inorganic fertilizers is prone to mismanagement and could lead to environmental degradation (Baqual, 2013). To ensure food security, continued crop production is vital for developing countries and this must be accomplished on sustainable bases to avoid jeopardizing the underlying bases of natural resources (Tarang et al., 2013).

Soils are important reservoirs of active carbon and play a major role in the global carbon and nitrogen cycle (Verena et al., 2010). As such, soil can be either a source or sink for atmospheric $\mathrm{CO}_{2}$ depending on land use and the management of soil and vegetation (Lal, 2005). Soil organic carbon and nitrogen stock has been demonstrated to be very sensitive to climate change, having a negative feedback which could enhance global warming (Batjes, 1996). A good estimation of carbon and nitrogen pools in the soils has been suggested as a means to help mitigate atmospheric $\mathrm{CO}_{2}$ and nitrous oxides. Despite the abundance of plant and animal wastes in Southeastern Nigeria, little information is available on the effect of these wastes on soil carbon and nitrogen stock as well as their effects on okra production.

\section{Materials and Methods}

\section{The Study Area}

The study was conducted at the Teaching and Research Farm of Federal University of Technology Owerri, Imo State, Southeastern Nigeria. The area lies between Latitude $5^{\circ} 21^{\prime} \mathrm{N}$ and $5^{\circ} 28^{\prime} \mathrm{N}$ and Longitude $7^{\prime}$ $02^{\circ} \mathrm{E}$ and $7^{\circ} 16^{\prime} \mathrm{E}$. The area has an average annual rainfall range of $1950 \mathrm{~mm}-2250 \mathrm{~mm}$ and annual temperature range of $27^{\circ} \mathrm{C}-30^{\circ} \mathrm{C}$ with average relative humidity of $79 \%$. The geologic material of soil in the study area is an ultisol and classified as Typic Haplustult (FDALR, 1985), derived from Coastal Plain Sands (Benin formation) of the Oligocene-Miocene geological era and are characterized by low organic matter, low cation exchange capacity and are highly leached (Onweremadu et al., 2011). Tropical rainforest is the dominant vegetation of the area, though with remarkable ecological diversity caused by anthropogenic activities, especially farming and deforestation resulting into depleted vegetation as a result of demographic pressure. Farming at subsistent level is a major socio economic activity of people in the area and fertility restoration in the area is by bush fallow and application of inorganic fertilizers. The location map of the study area is shown in Figure 1.

\section{Land Preparation}

A two year fallow land, dominated by shrubs and grasses was used for the study and was manually cleared using cutlass and hoes and mapped out into experimental plots. Composite soil samples were randomly collected for pre-planting soil analysis using soil auger at $0-30 \mathrm{~cm}$ depth. The samples were air dried at room temperature and sieved using $2 \mathrm{~mm}$ mesh sieve and then subjected to routine laboratory analysis using standard methods. The experimental plot was mapped out into nine treatment plots, each measuring $2 \times 2 \mathrm{~m}$ with inter plot distance of 1 $\mathrm{m}$ and replicated three times with inter block spacing of 2 $\mathrm{m}$. The beds were manually tilled with hoes and spades.

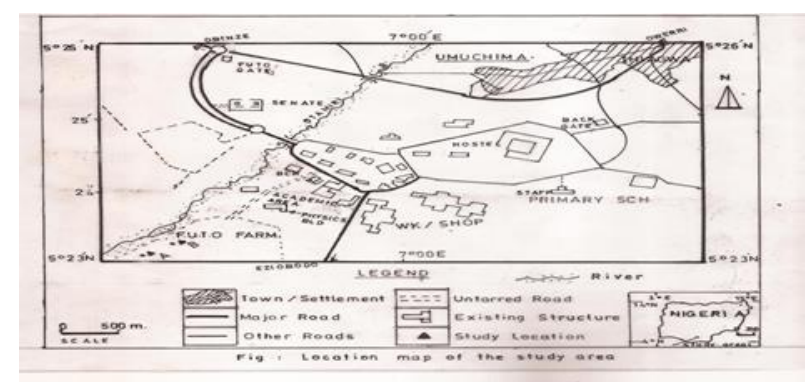

Fig 1 The location map of the study area

\section{Treatments and Experimental design}

The experiment was a factorial experiment with poultry droppings as factor A applied at 0,5 and $10 \mathrm{t} / \mathrm{ha}$ and saw dust ash as factor B applied at 0, 5 and $10 \mathrm{t} / \mathrm{ha}$. The treatments were laid out in randomized complete block design. After applying the treatments, the treatments were allowed to incubate for one week before planting the test crops. Some samples of poultry droppings and saw dust ash were collected and analysed for nutrient composition.

Okra (Abelmoshus esculentus) was planted at a distance of $50 \mathrm{~cm}$ on the experimental plots with three seeds per hole. This gave a plant population of 62500 okra plants/ha. A week after germination, the plants were thinned to a plant per stand. Growth attributes such as number of leaves, plant height and leaf area was measure at two weeks interval.

\section{Laboratory Analysis}

Physical properties of the soil: The particle size distribution of the soil (sand, silt and clay fractions) was determined by hydrometer method according to the procedure of Gee and Or (2002). Bulk density (BD) was determined by core methods according to Grossman and Reinsch (2002). Total porosity of the soil was calculated from the result of bulk density using the formula:

$\mathrm{TP}=[1-(\mathrm{BD} / \mathrm{pd}) \mathrm{x} 100]$

Where;

$\mathrm{TP}=$ Total Porosity

$\mathrm{pd}=$ Particle density $\left(2.65 \mathrm{~g} / \mathrm{cm}^{3}\right)$ and

$\mathrm{BD}=$ bulk density.

Gravimetric moisture content (GMC) was determined by the gravimetric method calculated mathematically as follows:

$$
\% \mathrm{GMC}=\{(\mathrm{W} 2-\mathrm{W} 3) /(\mathrm{W} 3-\mathrm{W} 1)\} \mathrm{X} 100
$$

Where;

$\mathrm{W} 1$ = weight of the can,

$\mathrm{W} 2$ = weight of wet sample + can,

$\mathrm{W} 3$ = weight of oven-dried sample + can. 
Soil chemical properties: Soil $\mathrm{pH}$ was determined in both water and in $\mathrm{KCl}$ using $\mathrm{pH}$ metre in soil / liquid suspension of 1: 2.5 according to Hendershot et al., (1993). Organic carbon was determined using chromic wet oxidation method according to Nelson and Somers (1982). Total nitrogen was determined by kjeldahl digestion method using concentrated $\mathrm{H}_{2} \mathrm{SO}_{4}$ and sodium copper sulphate catalyst mixture according to Bremner and Yeomans (1988). Available phosphorus was determined using Bray II solution method according to Olsen and Somers (1982). Exchangeable Mg and Ca were determined using ethylene diamine tetra acetic acid (EDTA) (Thomas, 1982) while exchangeable $\mathrm{K}$ and $\mathrm{Na}$ were extracted using $1 \mathrm{~N}$ Neutral ammonium acetate $\left(\mathrm{NH}_{4} \mathrm{OAC}\right)$ and then determined using flame photometer (Thomas, 1982). Exchangeable Acidity was measured titrimetrically using $1 \mathrm{~N} \mathrm{KCl}$ against $0.05 \mathrm{~N}$ Sodium hydroxide (Mclean, 1982) while effective cation exchange capacity was calculated from the summation of all exchangeable bases and total exchangeable acidity. Percentage Base Saturation (PBS) was calculated by the summation of the total exchangeable bases divided by effective cation exchange capacity and then multiplied by 100.

Determination of soil carbon and nitrogen stock: Soil carbon stock and nitrogen stock was calculated using the formula adopted by Batjes (1996) as;

$$
\begin{aligned}
& \mathrm{SCS}=\mathrm{SOC} \times \mathrm{BD} \times \text { area } \times \mathrm{D} / 10 \\
& \mathrm{SNC}=\mathrm{TSN} \times \mathrm{BD} \times \text { area } \times \mathrm{D} / 10 \\
& \text { Where; } \\
& \mathrm{SCS}=\text { Soil carbon stock }\left(\mathrm{g}^{2} \mathrm{~m}^{-1} \mathrm{~kg}^{-1}\right) \\
& \mathrm{SNC}=\text { soil nitrogen stock }\left(\mathrm{g}^{2} \mathrm{~m}^{-1} \mathrm{~kg}^{-1}\right) \\
& \mathrm{BD}=\text { bulk density }\left(\mathrm{g} / \mathrm{cm}^{3}\right) \\
& \mathrm{SOC}=\text { Soil organic carbon }(\mathrm{g} / \mathrm{kg}) \\
& \mathrm{TSN}=\text { total soil nitrogen }(\mathrm{g} / \mathrm{kg}) \\
& \mathrm{D} \quad=\text { soil depth }(\mathrm{m})
\end{aligned}
$$

Statistical analysis: Data collected were presented in tables and graphs. Data were subjected to Analysis of Variance (ANOVA). Significant means among treatments were separated using Least Significant Difference (LSD) at 5\% probability level while relationship between soil and nitrogen stock was determined through correlation analysis

\section{Results and Discussions}

\section{Nutrient Composition}

The physico-chemical properties of soil used in the study are presented in Table 1. Texturally, the soil was a sandy loam soil dominated by sand fraction. The soil was low in moisture content, strongly acidic, low in organic carbon and exchangeable bases. These properties showed that there is need to improve the fertility status of the soil for better crop performance since the essential nutrients were below the critical levels recommended by FAO
(2006). Appropriate management input is therefore needed for better food production in these soils.

Some selected nutrient content of the agricultural wastes used in the study are presented in Table 2. The wastes are rich in plant nutrient elements. Poultry droppings contained high values of nitrogen, phosphorus, organic carbon and magnesium than saw dust ash. Saw dust ash contained high value of potassium with high $\mathrm{pH}$. Therefore applying these wastes on the degraded soil of the study area is expected to improve the fertility level.

\section{Physical Properties}

Effects of the amendments on soil physical properties are presented in Table 3. Results showed that the amendments did not significantly $(\mathrm{p}<0.05)$ change the textural class of the soil which remained sandy loam. This observation was in agreement with Adaikwu et al., (2012) who stated that good soil management practices may slightly raise the clay fraction of the soil and improve soil productivity but cannot change the textural class. According to Fitz-Patrick (1986), textural class of the soil is a function of weathering in association with parent materials influenced by climate over time.

Table 1 Physicochemical properties of the soil before the study

\begin{tabular}{l|cc}
\hline \multicolumn{1}{c|}{ Soil property } & Unit & Values \\
\hline Sand & $\mathrm{g} / \mathrm{kg}$ & 921 \\
Silt & $\mathrm{g} / \mathrm{kg}$ & 15 \\
Clay & $\mathrm{g} / \mathrm{kg}$ & 64 \\
Textural Class & $\mathrm{g} / \mathrm{cm}^{3}$ & loam sand \\
Bulk density & $\%$ & 1.35 \\
Total porosity & $\mathrm{g} / \mathrm{kg}$ & 49.1 \\
Gravimetric moisture content & & 117.2 \\
$\mathrm{pH}\left(\mathrm{H}_{2} \mathrm{O}\right)$ & & 5.11 \\
$\mathrm{pH}(\mathrm{KCl})$ & $\mathrm{g} / \mathrm{kg}$ & 6.13 \\
Organic carbon & $\mathrm{g} / \mathrm{kg}$ & 0.36 \\
Total Nitrogen & $\mathrm{mg} / \mathrm{kg}$ & 14.3 \\
Available P & $\mathrm{cmol} / \mathrm{kg}$ & 1.4 \\
Exchangeable Calcium & $\mathrm{cmol} / \mathrm{kg}$ & 1.01 \\
Exchangeable $\mathrm{Mg}$ & $\mathrm{cmol} / \mathrm{kg}$ & 0.12 \\
Exchangeable K & $\mathrm{cmol} / \mathrm{kg}$ & 0.04 \\
Exchangeable Na & $\mathrm{cmol} / \mathrm{kg}$ & 0.32 \\
Exchangeable $\mathrm{H}$ & $\mathrm{cmol} / \mathrm{kg}$ & 0.59 \\
Exchangeable Al & $\mathrm{cmol} / \mathrm{kg}$ & 3.48 \\
Effective cation exchange capacity & $\%$ & 73.8 \\
Base saturation & & \\
\hline
\end{tabular}

Table 2 Chemical composition of the wastes used in the study

\begin{tabular}{l|cc}
\hline \multicolumn{1}{c|}{ Property } & $\begin{array}{c}\text { Saw dust } \\
\text { ash(SDA) }\end{array}$ & $\begin{array}{c}\text { Poultry } \\
\text { dropping (PD) }\end{array}$ \\
\hline $\mathrm{pH}\left(\mathrm{H}_{2} \mathrm{O}\right)$ & 9.55 & 6.83 \\
Nitrogen $(\mathrm{g} / \mathrm{kg})$ & 0.22 & 4.32 \\
Phosphorus $(\mathrm{mg} / \mathrm{kg})$ & 1.42 & 7.1 \\
Potassium $(\mathrm{g} / \mathrm{kg})$ & 4.30 & 3.21 \\
Organic carbon $(\mathrm{g} / \mathrm{kg})$ & 7.31 & 13.5 \\
$\mathrm{C} / \mathrm{N}$ & 33.2 & 3.13 \\
Calcium $(\mathrm{g} / \mathrm{kg})$ & 5.90 & 6.50 \\
Magnesium $(\mathrm{g} / \mathrm{kg})$ & 3.12 & 5.21 \\
\hline
\end{tabular}


The amendments significantly $(\mathrm{P}<0.05)$ reduced the soil bulk density when compared to the control plot. Soils amended with $10 \mathrm{t} / \mathrm{ha} \mathrm{PD}+10 \mathrm{t} / \mathrm{ha}$ SDA recorded the lowest soil bulk density $\left(1.07 \mathrm{~g} / \mathrm{cm}^{3}\right)$. Reduction of soil bulk density through application of agro-wastes agreed with the findings of Tekwa et al., (2010) who found out that application of rice mill husk reduced the soil bulk density. Improvement of soil properties such as soil aeration, moisture content and soil structure might increase soil microbes, increase soil organic matter that could reduce soil bulk density. Results of the effects of agro-wastes on soil total porosity showed that soils amended with the agro-wastes significantly $(\mathrm{P}<0.05)$ increased soil total porosity (Table 3 ). Results showed that among the treatment combination, soils amended with $10 \mathrm{t} / \mathrm{ha} \mathrm{PD}+10 \mathrm{t} / \mathrm{ha}$ SDA recorded the highest total porosity of $59.69 \%$. This observation was in concord with $\mathrm{Li}$ et al., (2011) who noted that application of organic wastes increases soil macro and meso pore volume due to an increase in organic matter content, better aggregation and water transmission rate.

The amendments significantly $(\mathrm{P}<0.05)$ increased soil gravimetric moisture content more than the control plot with plots treated with $10 \mathrm{t} / \mathrm{ha} \mathrm{PD}+10 \mathrm{t} / \mathrm{ha} \mathrm{SDA}$ recording the highest gravimetric moisture content of 369.17. Increase in gravimetric moisture content with addition of these wastes could be due to an increase in total porosity, reduction in soil bulk density and better soil aggregation. This finding agreed with the report of Mbah and Nneji (2010) that water holding capacity depends on soil total porosity and the size distribution of its pores.

\section{Chemical Properties}

Effects of treatments on soil chemical properties are shown in Table 4. Results showed that the treatments significantly $(\mathrm{P}<0.05)$ increased soil $\mathrm{pH}$ when compared to control. Plots amended with $10 \mathrm{t} / \mathrm{ha} \mathrm{PD}+10 \mathrm{t} / \mathrm{ha}$ SDA recorded the highest values of soil $\mathrm{pH}$ in water (5.29) and in $\mathrm{KCl}$ (4.75). The same rate also recorded the highest values of organic carbon $(8.67 \mathrm{~g} / \mathrm{kg})$, total nitrogen $(0.74$ $\mathrm{g} / \mathrm{kg}$ ), and available phosphorus (18.10 $\mathrm{mg} / \mathrm{kg})$ when compared to other treatments. Similarly the same trend was observed in exchangeable bases and, effective cation exchange capacity and base saturation. Plots amended with $10 \mathrm{t} / \mathrm{ha} \mathrm{PD}+10 \mathrm{t} / \mathrm{ha} \mathrm{SDA}$ recorded the lowest total exchangeable acidity of $0.53 \mathrm{cmol} / \mathrm{kg}$. Increase in organic carbon with application of these organic wastes could be attributed to increase in gravimetric moisture retention and reduced bulk density which created a favourable environment for microbial activity, decomposition and mineralization. These result to an increase in soil $\mathrm{pH}$ and increase in basic cations. These observations agreed with the findings of Akanbi, et al., (2002) who observed that application of organic wastes improved soil organic matter and increased moisture retention. Increase in exchangeable cations with application of these agro wastes could be attributed to an increase in the $\mathrm{pH}$ of the soil which promotes the availability and uptake of these nutrient elements by plants. Also, increase in soil organic matter, improved soil porosity and gravimetric moisture content due the application of the amendments could be responsible an increase in exchangeable cations.

\section{Carbon and Nitrogen Stocks}

Results of the effects of agro-wastes on soil carbon and nitrogen stocks are presented in Figure 2. Plots amended with agro-wastes significantly $\quad(\mathrm{P}<0.05)$ increased the carbon stock of the soil when compared to control plot. Plots amended with $10 \mathrm{t} / \mathrm{ha} \mathrm{PD}+10 \mathrm{t} / \mathrm{ha}$ SDA recorded the highest soil carbon stock of $92.44 \mathrm{~g}^{2} \mathrm{~m}^{-1} \mathrm{~kg}^{-1}$ as compared to control that recorded $71.0 \mathrm{~g}^{2} \mathrm{~m}^{-1} \mathrm{~kg}^{-1}$.

Similarly, application of agro-wastes significantly $(\mathrm{P}<0.05)$ increased soil nitrogen stock with plots amended with $10 \mathrm{t} / \mathrm{ha} \mathrm{PD}+10 \mathrm{t} / \mathrm{ha} \mathrm{SDA}$ recording the highest soil nitrogen stock of $3.11 \mathrm{~g}^{2} \mathrm{~m}^{-1} \mathrm{~kg}^{-1}$ as compared to control that recorded $1.57 \mathrm{~g}^{2} \mathrm{~m}^{-1} \mathrm{~kg}^{-1}$. Low value of soil carbon and nitrogen stocks in the control plot could be attributed to low organic matter, increase in soil bulk density which reduced water infiltration, soil aeration and soil biodiversity and rate of decomposition of organic material. Similar studies have proved that conversion of forest land into cultivation without additional organic inputs increases global warming by reducing the amount of soil carbon stock (Chen and Xu, 2010). These findings were also in line with Anger (2005) who discovered after application of organic manure, an increase in the soil carbon stock. Angers (2005) observed a 36\% increase in soil carbon stock after application of organic wastes on a degraded soil.

Table 3 Effect of saw dust ash and poultry manure on soil physical properties

\begin{tabular}{l|ccccccc}
\multicolumn{1}{c|}{ Treatment } & $\begin{array}{c}\text { Sand } \\
\mathrm{g} / \mathrm{kg}\end{array}$ & $\begin{array}{c}\text { Silt } \\
\mathrm{g} / \mathrm{kg}\end{array}$ & $\begin{array}{c}\text { Clay } \\
\mathrm{g} / \mathrm{kg}\end{array}$ & Textural class & $\begin{array}{c}\text { BD } \\
\mathrm{g} / \mathrm{cm}^{3}\end{array}$ & $\begin{array}{c}\text { TP } \\
\%\end{array}$ & $\begin{array}{c}\text { GMC } \\
\mathrm{g} / \mathrm{kg}\end{array}$ \\
\hline Control & 922.93 & 16.13 & 60.93 & Sandy loam & 1.37 & 48.40 & 116.80 \\
5 t/ha PD & 882.93 & 19.47 & 40.93 & Sandy loam & 1.30 & 51.07 & 144.90 \\
10 t/ha PD & 912.93 & 12.80 & 47.60 & Sandy loam & 1.20 & 55.36 & 224.13 \\
5t/ha SDA & 912.93 & 39.47 & 44.27 & Sandy loam & 1.19 & 56.63 & 123.10 \\
5t/ha PD + 5t/ha SDA & 899.60 & 22.80 & 84.27 & Sandy loam & 1.27 & 52.20 & 243.87 \\
5t/ha PD + 10t/ha SDA & 882.93 & 32.80 & 30.97 & Sandy loam & 1.24 & 55.00 & 241.33 \\
10t/ha SDA & 982.93 & 6.13 & 45.93 & Sandy loam & 1.29 & 52.87 & 168.23 \\
10t/ha PD + 5t/ha SDA & 949.60 & 6.13 & 11.60 & Sandy loam & 1.26 & 54.10 & 311.00 \\
10t/ha PD + 10t/ha SDA & 929.60 & 29.47 & 40.93 & Sandy loam & 1.07 & 59.69 & 369.17 \\
LSD(0.05) & NS & NS & NS & & 0.076 & 5.278 & 27.71 \\
\hline BD & & & &
\end{tabular}

$\mathrm{BD}=$ bulk density, $\mathrm{TP}=$ Total porosity, $\mathrm{GMC}=$ gravimetric moisture content, $\mathrm{PD}=$ poultry droppings, SDA = saw dust ash 
Table 4 Effect of agro-wastes on soil chemical properties

\begin{tabular}{|c|c|c|c|c|c|c|c|c|c|c|c|c|c|}
\hline Treatment & $\begin{array}{c}\mathrm{pH} \\
\mathrm{H}_{2} \mathrm{O}\end{array}$ & $\begin{array}{l}\mathrm{pH} \\
\mathrm{KCl}\end{array}$ & $\begin{array}{l}\mathrm{OC} \\
\mathrm{g} / \mathrm{kg}\end{array}$ & $\begin{array}{l}\mathrm{TN} \\
\mathrm{g} / \mathrm{kg}\end{array}$ & $\mathrm{C} / \mathrm{N}$ & $\begin{array}{l}\text { Av. P } \\
\mathrm{Mg} / \mathrm{kg}\end{array}$ & $\begin{array}{c}\text { Ex. Ca } \\
\mathrm{Cmol} / \mathrm{kg}\end{array}$ & $\begin{array}{c}\text { Ex. } \mathrm{Mg} \\
\mathrm{Cmol} / \mathrm{kg}\end{array}$ & $\begin{array}{c}\text { Ex. K } \\
\text { Cmol/kg }\end{array}$ & $\begin{array}{c}\text { Ex. Na } \\
\mathrm{Cmol} / \mathrm{kg}\end{array}$ & $\begin{array}{c}\text { TEA } \\
\mathrm{Cmol} / \mathrm{kg}\end{array}$ & $\begin{array}{c}\text { ECEC } \\
\mathrm{Cmol} / \mathrm{kg}\end{array}$ & $\begin{array}{l}\mathrm{BS} \\
\%\end{array}$ \\
\hline Control & 5.01 & 4.14 & 6.47 & 0.55 & 11.67 & 15.23 & 1.50 & 1.09 & 0.13 & 0.03 & 0.99 & 3.74 & 73.30 \\
\hline $5 \mathrm{t} / \mathrm{ha} \mathrm{PD}$ & 5.13 & 4.44 & 7.47 & 0.64 & 11.67 & 16.25 & 2.25 & 1.36 & 0.17 & 0.04 & 0.62 & 4.45 & 86.03 \\
\hline $10 \mathrm{t} / \mathrm{ha} \mathrm{PD}$ & 5.13 & 4.53 & 7.61 & 0.65 & 11.73 & 16.37 & 2.33 & 1.39 & 0.37 & 0.03 & 0.66 & 4.79 & 86.30 \\
\hline 5t/ha SDA & 5.25 & 4.53 & 7.23 & 0.62 & 11.57 & 16.57 & 2.30 & 1.34 & 0.49 & 0.04 & 0.62 & 4.79 & 87.00 \\
\hline 5t/ha PD+5t/ha SDA & 5.26 & 4.55 & 7.67 & 0.65 & 11.73 & 16.93 & 2.44 & 1.45 & 0.59 & 0.03 & 0.59 & 5.09 & 88.43 \\
\hline $5 \mathrm{t} / \mathrm{ha} \mathrm{PD}+10 \mathrm{t} / \mathrm{ha}$ SDA & 5.27 & 4.55 & 8.18 & 0.71 & 11.53 & 17.40 & 2.58 & 1.55 & 0.68 & 0.03 & 0.53 & 5.38 & 90.07 \\
\hline 10t/ha SDA & 5.26 & 4.57 & 7.41 & 0.63 & 11.63 & 16.87 & 2.43 & 1.49 & 0.64 & 0.04 & 0.49 & 5.08 & 90.40 \\
\hline 10t/ha PD+5t/ha SDA & 5.27 & 4.70 & 8.41 & 0.72 & 11.73 & 17.40 & 2.54 & 1.66 & 0.72 & 0.06 & 0.51 & 5.49 & 90.60 \\
\hline 10t/ha PD+10t/ha SDA & 5.29 & 4.75 & 8.67 & 0.74 & 11.67 & 18.10 & 2.56 & 1.74 & 0.81 & 0.06 & 0.53 & 5.69 & 90.77 \\
\hline$\% \mathrm{CV}$ & 0.10 & 0.70 & 1.10 & 1.00 & 0.60 & 0.70 & 5.30 & 2.60 & 5.40 & 42.30 & 9.20 & 3.60 & 1.20 \\
\hline $\operatorname{LSD}(0.05)$ & 0.02 & 0.09 & 0.48 & 0.04 & 0.26 & 0.49 & 0.3 & 0.1 & 0.09 & 0.03 & 0.15 & 0.42 & 2.83 \\
\hline
\end{tabular}

Av.: Available, Ex: Exchangeable, $\mathrm{OC}=$ organic carbon, $\mathrm{TN}=$ total $\mathrm{N}, \mathrm{C} / \mathrm{N}=$ carbon to nitrogen ratio, $\mathrm{TEA}=$ total exchangeable acidity, ECEC $=$ effective cation exchange capacity, $\mathrm{BS}=$ base saturation, $\mathrm{PD}=$ poultry dropping, SDA = saw dust ash

Table 5 Relationship between soil carbon and nitrogen stocks on soil physico-chemical properties

\begin{tabular}{l|cc}
\hline \multicolumn{1}{c|}{ Soil property } & SCS & SNS \\
\hline $\mathrm{BD}$ & 0.2890 & 0.3158 \\
$\mathrm{BS}$ & 0.3834 & 0.3785 \\
$\mathrm{C} / \mathrm{N}$ & -0.008 & -0.1680 \\
$\mathrm{Ca}$ & 0.2975 & 0.2916 \\
$\mathrm{Clay}$ & -0.3290 & -0.3585 \\
$\mathrm{ECEC}$ & 0.3195 & 0.3191 \\
$\mathrm{~K}$ & 0.3041 & 0.3271 \\
$\mathrm{MC}$ & 0.3645 & 0.3270 \\
$\mathrm{Mg}$ & $0.5035^{*}$ & 0.4821 \\
$\mathrm{Na}$ & -0.1630 & -0.2420 \\
$\mathrm{OC}$ & $0.6128^{* *}$ & $0.5834^{*}$ \\
$\mathrm{pH}\left(\mathrm{H}_{2} \mathrm{O}\right)$ & $0.5221 *$ & $0.5150^{*}$ \\
$\mathrm{Sand}$ & 0.1841 & 0.1658 \\
$\mathrm{Silt}$ & -0.1480 & -0.0930 \\
$\mathrm{TEA}$ & -0.4370 & -0.4230 \\
$\mathrm{TEB}$ & 0.3703 & 0.3669 \\
TN & $0.6167 * *$ & $0.6101 * *$ \\
TP & -0.1980 & -0.1951
\end{tabular}

\section{Growth and Yield of Okra}

Effects of agro-wastes on the growth and yield of okra are presented in Figure 3. Results showed that application of the agro-wastes significantly $(\mathrm{P}<0.05)$ increased the growth attributes of the crop. Plots amended with $10 \mathrm{t} / \mathrm{ha}$ $\mathrm{PD}+10 \mathrm{t} / \mathrm{ha}$ SDA (T9) recorded the highest value of okra height $(48.8 \mathrm{~cm})$ when compared to other treatments. Similarly, the trend of performance on the number of okra leaves followed the sequence $\mathrm{T} 9>\mathrm{T} 8>\mathrm{T} 5>\mathrm{T} 6=\mathrm{T} 7>$ $\mathrm{T} 3>\mathrm{T} 4>\mathrm{T} 2>\mathrm{T} 1$. Effect of the amendments on the leaf area of okra followed the sequence $\mathrm{T} 9>\mathrm{T} 7>\mathrm{T} 3>\mathrm{T} 8>$ $\mathrm{T} 5>\mathrm{T} 4>\mathrm{T} 2>\mathrm{T} 6>\mathrm{T} 1$. The highest fresh okra pod yield of $3500 \mathrm{~kg} / \mathrm{ha}$ was recorded from plots amended with 10 $\mathrm{t} / \mathrm{ha} \mathrm{PD}+10 \mathrm{t} / \mathrm{ha}$ SDA (T9) and the sequence of performance was $\mathrm{T} 9>\mathrm{T} 8>\mathrm{T} 5>\mathrm{T} 6=\mathrm{T} 7>\mathrm{T} 3=\mathrm{T} 4>$ T2 > T1. Similar works by Brar et al., (2001) and Jayaprakash et al., (2003) observed a significant difference with $30 \mathrm{t} / \mathrm{ha}$ farm yard manure application on maize production. Increase in the growth and yield of okra with application of these agro -wastes could be attributed to the plant nutrient elements supplied by these amendments as well as the improvement of soil physical condition such as reduced bulk density, increase in total porosity and water retention as well as increase in soil organic matter and soil $\mathrm{pH}$. These attributes play significant role in increasing soil aeration and soil biodiversity (Jayaprakash et al., 2003) with an attendant high crop yield. These findings are in concord with previous works by Kumar and Puri (2001), Verma et al (2003).

\section{Relationships}

Relationship between soil carbon stock (SCS) and soil nitrogen stock (SNC) with soil physicochemical properties are presented in Table 5. There was significant positive correlation between SCS with organic carbon $(\mathrm{r}=$ $0.6128)$, exchangeable $\mathrm{Mg}(\mathrm{r}=0.5035)$, total nitrogen $(\mathrm{r}=$ $0.6167)$ and soil $\mathrm{pH}(\mathrm{r}=0.5221)$. SNS correlated positively with organic carbon $(\mathrm{r}=0.5834)$, total nitrogen $(\mathrm{r}=0.6101)$ and soil $\mathrm{pH}(\mathrm{r}=5150)$. Increase in soil $\mathrm{pH}$ increases soil biodiversity and mineralization of organic matter with anticipated increase in soil carbon stock and nitrogen stock. Soil moisture retention influences the level of carbon dioxide fluxes in the soil which may in one way or the other affect soil microbial biomass and potential carbon and nitrogen (Haney et al., 2004). 

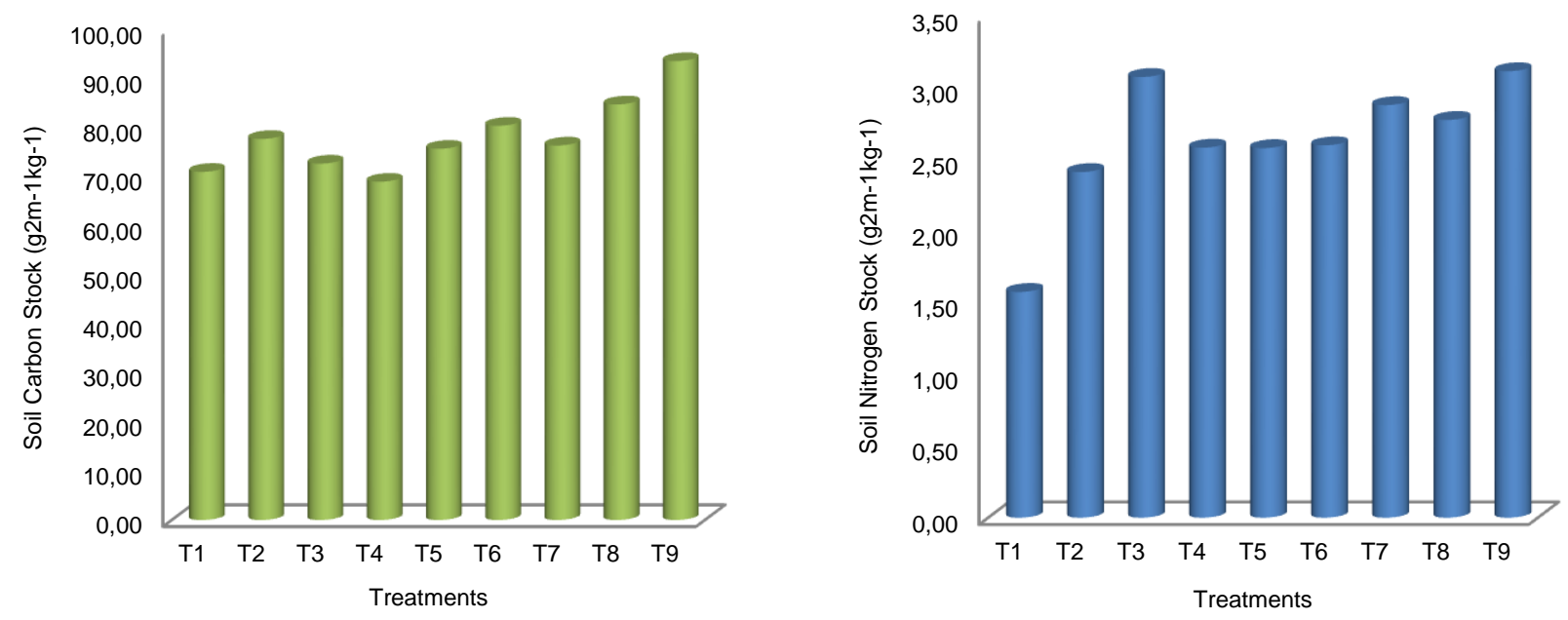

Fig 2 Effect of saw dust ash and poultry droppings on soil carbon and nitrogen stocks of the treated soils (LSD=0.05). $(\mathrm{T} 1=$ control, $\mathrm{T} 2=5 \mathrm{t} / \mathrm{ha} \mathrm{PD}, \mathrm{T} 3=10 \mathrm{t} / \mathrm{ha} \mathrm{PD}, \mathrm{T} 4=5 \mathrm{t} / \mathrm{ha} \mathrm{SDA}, \mathrm{T} 5=5 \mathrm{t} / \mathrm{ha} \mathrm{PD}+5 \mathrm{t} / \mathrm{ha} \mathrm{SDA}, \mathrm{T} 6=5 \mathrm{t} / \mathrm{ha} \mathrm{PD}+10 \mathrm{t} / \mathrm{ha} \mathrm{SDA}, \mathrm{T} 7=10 \mathrm{t} / \mathrm{ha} \mathrm{SDA}, \mathrm{T} 8=$ $10 t / h a \mathrm{PD}+5 \mathrm{t} / \mathrm{ha} \mathrm{SDA}, \mathrm{T} 9=10 \mathrm{t} / \mathrm{ha} \mathrm{PD}+10 \mathrm{t} / \mathrm{ha} \mathrm{SDA})$
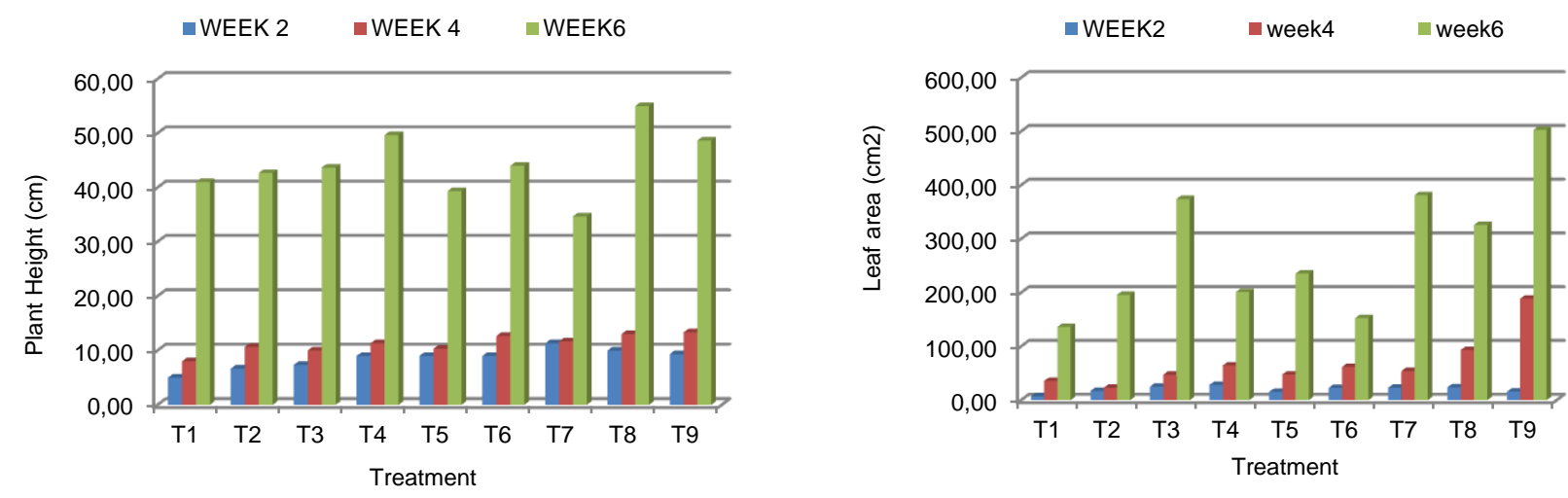

$\because$ WEEK2 $\quad$ WEEK $4 \quad$ WEEK6
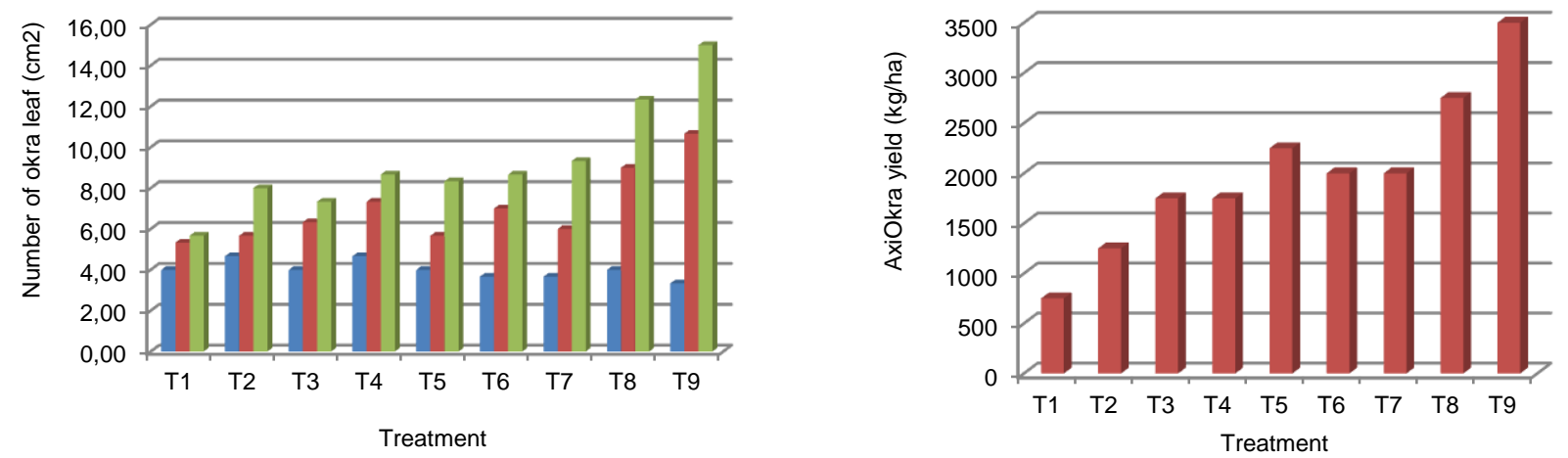

Fig 3 Effect of saw dust ash and poultry droppings on the growth and yield of okra (LSD=0.05).

$(\mathrm{T} 1=$ control, T2 $=5 \mathrm{t} / \mathrm{ha} \mathrm{PD}, \mathrm{T} 3=10 \mathrm{t} / \mathrm{ha} \mathrm{PD}, \mathrm{T} 4=5 \mathrm{t} / \mathrm{ha} \mathrm{SDA}, \mathrm{T} 5=5 \mathrm{t} / \mathrm{ha} \mathrm{PD}+5 \mathrm{t} / \mathrm{ha} \mathrm{SDA}, \mathrm{T} 6=5 \mathrm{t} / \mathrm{ha} \mathrm{PD}+10 \mathrm{t} / \mathrm{ha} \mathrm{SDA}, \mathrm{T} 7=10 \mathrm{t} / \mathrm{ha} \mathrm{SDA}, \mathrm{T} 8$ $=10 \mathrm{t} / \mathrm{ha} \mathrm{PD}+5 \mathrm{t} / \mathrm{ha} \mathrm{SDA}, \mathrm{T} 9=10 \mathrm{t} / \mathrm{ha} \mathrm{PD}+10 \mathrm{t} / \mathrm{ha} \mathrm{SDA})$ 


\section{Conclusion}

As a way of revitalizing the soil fertility status of a degraded soil in Owerri, Southeastern Nigeria and finding out an appropriate utilization of abundant agricultural wastes predominant in the region for food and environmental sustainability, field trial was conducted to evaluated the effect of saw dust ash and poultry droppings on soil physicochemical properties, soil carbon and nitrogen stock and effect on growth and yield of okra. Results showed that these wastes contain plant nutrient element that can sustain okra production in a degraded soil and there application on soil increased soil carbon and nitrogen stock.

\section{Recommendation}

Among the treatment and treatment combinations investigated, application of $10 \mathrm{t} / \mathrm{ha} \mathrm{PD}+10 \mathrm{t} / \mathrm{ha} \mathrm{SDA}$ proved superior over other treatments in improving soil physicochemical properties, soil carbon and nitrogen stocks as well as growth and yield of okra in the area. Therefore, combining $10 \mathrm{t} /$ ha of poultry dropping with 10 $\mathrm{t} / \mathrm{ha}$ of saw dust ash is recommended for okra production and improvement of soil carbon and nitrogen stocks.

\section{Acknowledgement}

The research team is grateful to Soil Science and Technology laboratory technologists for their assistance in the laboratory works as well as to farm manager, Federal University of Technology Teaching and Research Farm.

\section{References}

Adaikwu AO, Obi ME, Ali A. 2012. Assessment of degradation status of soil in selected area s of Benue State Southern Guinea Savannah of Nigeria. Nigerian Journal of Soil Science 22(1): $171-180$

Adesodun JK, Odejimi OE. 2009. Structural Stability and Carbon Nitrogen potentials of a tropical Alfisol as influenced by pigcomposted manure. In: $5^{\text {th }}$ National Conference of Organic Agriculture Project in Tertiary Institutions in Nigeria at Federal University of Technology Owerri $265-271$.

Ajaz A, Lone B, Allai A, Nehvi FA. 2013. Growth, yield and economics of baby corn (Zea mays L.) as influenced by Integrated Nutrient Management (INM) practices. African Journal of Agric. Research 8(3): 4537 - 4540.

Akanbi WB, Adediran JB, Togun AO, Shobulo RA. 2002. Effect of organic based fertilizer on growth, yield and storage life of tomato (lypersicon esculentum). BioSci. Res. Communication 12: $439-444$.

Angers DA. 2005. Greenhouse gas contributions of agricultural soils and potential mitigation practices in Eastern Canada. Soil Till. Res. 83: 53 - 72.

Anino CO, Mugalavai V, Kamau EH. 2013. A study on impact of climate change on the food and nutrition security in children of small scale farmer households of Migori area. Global Journal of Biology, Agriculture and Health Sciences 2(1): 67-71

Asadu CL, Nweke FI. 1999. Soils of arable crop fields in SubSaharan Africa. Focus on cassava growing areas. In: Advances in Crop Engineering for the $21^{\text {st }}$ Century. Proc. of a Conference on New Genetic Engineering, $23-27^{\text {th }}$ Feb.
Baqual MF. 2013. Economics of using bio-fertilizers and their influence on certain quantitative traits of mulberry. African Journal of Agric. Research 8(27): 3628 - 3631.

Batjes NH. 1996. Total carbon and nitrogen in the soil of the world. European Journal of Soil Science 47: $151-163$.

Brar BS, Dhillon WS, China HS. 2001. Integrated use of farm yard manure and ignorance fertilizers in maize (Zea mays). Indian $\mathrm{J}$. Agric. Sci. 71(9): 605 - 607.

Bremner JM, Yeomans JC. 1988. Laboratory Techniques for determination of different forms of nitrogen. In: J, R. Wilson (ed.). Advances in Nitrogen Cycling in Agricultural Ecosystem $339-414$.

Chen C, Xu Z. 2010. Forest ecosystem responses to environmental changes: The key regulatory role of biogeochemical cycling. Journal of Soils Sediments 10: 210 - 214.

FAO. 2006. Guidelines for soil description. Fourth edition, Food and Agricultural Organization of the United Nation 97.

Federal Department of Agriculture and Land Resources FDALR. 1985. Reconnaissance soil survey of Anambra State of Nigeria. Soil Reports 1985. Federal Dept. of Agric. Land Resources, Lagos- Nigeria.

Fitz-Patrick FA. 1986. An introduction to soil science . $2^{\text {nd }}$ Edition. Longman Scientific and Technical and John Willy and Sons Int. New York 266.

Gee GW, Or D. 2002. Particle size analysis. In: Methods of Soil Analysis. Dan. D. J and Topps G.C (Ed.). Part 4, Physical Methods. Soil Sci. Soc. of America Book Series. No. 5, ASA and SSSA Madison, WI 225 - 293.

Grossman RB, Reinch TG. 2002. Bulk density and linear extensibility in methods of soil analysis. Part 4 Physical Methods. Dane, J.H and G.C Topp (eds.). Soil Science Society of Am. Book Series, No 5 ASA and SSA Madison, WI $201-$ 228.

Haney RL, Franzluebbers AJ, Porter EB, Hons FM, Zuberer DA. 2004. Soil carbon and nitrogen mineralization. In: Influence of drying temperature. Soil Sci Soc. of America 68: 489 - 492.

Hendershot LH, Duquette M. 1993. Soil reaction and exchangeable acidity. In: Soil Sampling and Methods of Soil Analysis. Carter, M.R. (Ed.). Canadian Soc. Soil Sci. Lewis Pub., London 141 145.

Jayaprakash TC, Wagalikar VP, Pujari BT, Setty RA. 2003. Effect of organics and inorganics on yield attributes of maize under irrigation Karnataka. J. Agric. Sci. 16(3):451 - 453.

Kalu C, Modugu WW, Ubochi I. 2009. Evaluation of soil waste management policy in Benin Metropolis, Edo State, Nigeria. African Sci. 10: $1-7$.

Kumar MV, Peri NS. 2001. Studies on character association and path efficient for grain and oil Content in maize. Annals of Agric. 73 - 28.

Lal R. 2005. No-till farming and environment quality. In: Simposio sobre Plantio direto e Meio ambiente; Sequestro de carbono e qualidade da agua 29 - 37.

Li JT, Zhong XL, Wang F, Zhao QG. 2011. Effect of poultry litter and livestock manure on soil physical and biological indicators in a rice-wheat rotation system. Plant Soil Environ 57(8): 351356.

Mbah CN, Nneji RK. 2010. Effect of Different Crop Residue Management Techniques on Selected Soil Properties and Grain Production of Maize. J. Appl. Sci. Res. 6(2): 151 - 155.

Mclean ED. 1982. Soil pH and lime requirements in Page A.L. (Ed). Methods of soil analysis part 2. Chemical and microbiological properties (2nd Ed.). Agronomy series No. SSSA. Maidison, Wis. USA 199 - 234.

Nelson DW, Somers LE. 1982. Total organic carbon and matter. In: Methods of soil analysis. Part 2 chemical and microbiological properties ( $2^{\text {nd }}$ ed.). Agronomy Series No.9, ASA, SSA, Maidison, Wis.USA 570.

NwachukwuI OI. 2008. Contaminant source as a factor of soil heavy metal toxicity and its availability to plants. Environmental Research Journal. 2: 322 - 326. 
Olsen SR, Somers IE. 1982. Soil available phosphorus. In: D. L. Sparks, A. L. Page, P.A. Hennke, K. H Loppez, E.N. Solanpour and M.E Summers ( $2^{\text {nd }}$ ed.). Methods of Soil Analysis, Part 2. Agron., Mono. ASA and SSSA Madison, USA.

Onweremadu EU, Ihem EE, Onwudike SU, Ndukwu BN, Idigbor CM, Asiabaka CC. 2011. Evaluation of selected physical properties of soils as influenced by legumes and prominol - $\mathrm{P}$ fertilization. Journal of Emerging Trends in Engineering and Applied Science (JETEAS) 2(2): 198 - 202.

Tarang E, Ramroudi M, Galavi M, Dahmardeh M, Mohajeri F. 2013. Effects of Nitrogen bio-fertilizer with chemical fertilizer on yield and yield components of grain corn (cv. Maxima). International Journal of Agri. Science 3(5): 400 - 405

Tariq HK, Kamal-Sh Q, Salahaddin aa . 2013. Rate of soil aggregates disintegration as affected by type and rate of manure application and water quality. International Journ. of Plant, Animal and Environmental Sciences $94-102$.
Tekwa IJ, Olawoye HU, Yakubu H. 2010. Comparative effects of separate incorporation of cow dung and rice husk materials on nutrient status of some lithosols in Mubi. International Journal of Agric. And Biology 12: $857-860$.

Thomas GW. 1982. Exchangeable Cations. In: A. L. Page, A. Miller and D.R. Keeney ( $2^{\text {nd }}$ Ed.). Methods of Soil Analysis. Part 2, ASA and SSSA, Madison, WI $159-166$.

Verena D, Peter F, Karl S. 2010. Layer specific analysis and spatial prediction of soil organic carbon using terrain attributes and erosion modelling. Soil Sci. Society of America Journal 74: 922 -935 .

Verma CP, Pradesh k, Sing HV, Verma RN. 2003. Effects of soil condition and fertilizers on yield and economic of maize in maize-wheat sequence. Crop Res. Journal. 25(3): 449-453. 